\title{
Isolation of Betulinic acid from the stem bark and root of Uapaca guineensis
}

\section{Abdulrazaq Ogunmoye $1^{1}$, Ibrahim Oladosu $2^{2}$, Patricia Onocha $3^{2}$, Iqbal Choudhary $4^{3}$}

${ }^{1}$ Department of Chemical Sciences, Faculty of Science, Olabisi Onabanjo University, Ago Iwoye, Nigeria

${ }^{2}$ Chemistry Department, Faculty of Science, University of Ibadan, Nigeria

${ }^{3}$ H.E.J. Research Institute of Chemistry, ICCBS, University of Karachi, Pakistan.

\section{Correspondence}

Abdulrazaq Omotunde Ogunmoye, Department of Chemical Sciences, Faculty of Science, Olabisi Onabanjo University, Ago Iwoye, Nigeria.

Email:omotunde.ogunmoye@oouagoiwoye. edu.ng

\section{Funding information}

Grant sponsor: TWAS/ICCBS Postgraduate Fellowship.

\begin{abstract}
:
Aims: To investigate the stem bark and root of Uapaca guineensis extracts, with a view of isolating betulinic acid across the various part of the plant based on its reported biological activities.

Study design: The design included extraction of $U$. guineensis stem bark and root with ethanol and subsequent partitioning, isolation and characterization of the possible isolated compounds.

Place and Duration of Study: Chemistry Department (Organic Unit), Faculty of Science, University of Ibadan, Nigeria and H.E.J. Research Institute of Chemistry, ICCBS, University of Karachi, Pakistan between March 2012 and April 2013.

Methodology: The air-dried and pulverized stem bark and root of $U$. guineensis $(0.5 \mathrm{~kg}$ each) were separately extracted with aqueous ethanol $(80 \%)$ for 72 hour at room temperature, filtered, concentrated on rotatory evaporator at $37^{\circ} \mathrm{C}$ and then stored in a desiccator. The ethanol extracts of the stem bark was partitioned successively with n-hexane, dichloromethane and methanol. The dichloromethane, methanol and ethanol extracts (root) were then chromatographed and the isolated compounds subjected to various spectroscopic analysis.

Results: The air-dried and pulverized stem bark and root of $U$. guineensis ( $0.5 \mathrm{~kg}$ each) extracted with ethanol and then partitioned yielded dichloromethane $(6.9 \mathrm{~g})$, methanol (17.9) and the ethanol (12.9) extracts. The chromatography of the various extracts results in the formation of whitish powder that are UV inactive and also gave single spot each with cerium sulphate coded as DBG-D ${ }_{13}(25.0 \mathrm{mg}), \mathrm{MBG}-\mathrm{Q}_{3}$ $(6.1 \mathrm{mg})$ and $E R G-E_{7}(20.0 \mathrm{mg})$ for dichloromethane, Methanol and Ethanol extracts respectively. The structures were unequivocally

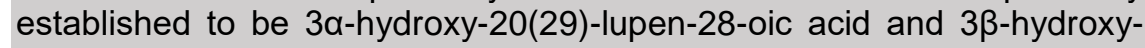
20(29)-Iupen-28-oic acid by ${ }^{1} \mathrm{HNMR},{ }^{13} \mathrm{CNMR}, 2 \mathrm{D}-\mathrm{NMR}, \mathrm{IR}, \mathrm{UV}$ and MS spectra analysis as well as by comparison of the spectra data with previously reported values.
\end{abstract}

Keywords: Uapaca guineensis, Euphorbiaceae, Betulinic acid 


\section{INTRODUCTION}

Uapaca belong to a genus of the family Euphorbiaceae $[1,2]$ and is in the sub-tribe Uapacinae. It comprises approximately 105 species, of which 49 are confined to continental Africa. The species described so far in the genus are trees of 20 to $25 \mathrm{~m}$ high with about $60 \mathrm{~cm}$ in diameter [3, 4].

Phytochemical studies on extract of the genus revealed the presence of terpenoids, saponins, alkaloids and sterols [5]. The presence of phenolic compounds including tannins, gallotannins and flavanols from fruits of Uapaca kirkiana was also reported [6]. Betulinic acid and antidesmone as constituents of Uapaca nitida and Uapaca robynsii respectively were also reported $[7,8]$.

Uapaca guineensis Mull. Arg. (Euphorbiaceae) commonly called false mahogany and "Ewe akun" in the western part of Nigeria grows in humid localities, mixed evergreen forest, bush land on steep slopes and sea-level up to $1100 \mathrm{~m}$ altitude. They are widely distributed from West Africa to Democratic Republic of Congo. It is a tree of about $30 \mathrm{~m}$ high, rarely more, bore to $4 \mathrm{~m}$ girth by $13 \mathrm{~m}$ long, usually much less, more or less fluted with large stilt-roots up to $3 \mathrm{~m}$ high, dense low-branching crown and leaves may reach 30 $\mathrm{cm}$ long by $15 \mathrm{~cm}$ wide. The wood is hard, durable and moderately heavy, and when quarter-sawn is attractively figured with a silver grain $[9,10]$.

The isolation of substantial amounts of betulinic acid as almost the sole component from Uapaca species as well as the in vitro antitrypanosomal activity have been reported [4, 18]

The pharmacological activities of this species in Western and Eastern Africa folk medicine include antiinflammation, treatment of fever, pain, sexual dysfunction and bacterial diseases [16, 17 and 8].

In Nigeria, the pulp is made into a refreshing drink; leaves are used to wrap kola nuts and the roots to treat male impotence. The wood is used locally in carpentry and to make planks, railway sleepers, beams, furniture, beds and kitchen utensils. It also produces good firewood and charcoal [7]. The stiltrooted habit of this riverside species has raised the suggestion that it is able to stabilise river-banks, curb was and break the flood movement of water in dryforest Zone Rivers [12].

Considering the report on the biological activities of betulinic acid from this family, the study was therefore aimed at investigating the stem bark and root of $U$. guineensis extracts, with a view of isolating betulinic acid across the various part of the plant.

\section{MATERIAL AND METHODS}

\section{Plant materials}

LASU Journal of Research and Review in Science
Uapaca guineensis plant was collected at Epe, Lagos, Nigeria. It was authenticated at Federal Research Institute of Nigeria (FRIN), with FHI number 108457 and a voucher specimen of the specie was deposited at the herbarium.

\section{Extraction and fractionation of Plant material}

Plant material were separated into its selected parts; $500 \mathrm{~g}$ each of stem bark and root were air dried, pulverized, exhaustively percolated separately with aqueous ethanol (80\%) and intermittently agitated in ultrasonic water bath for 72 hour at room temperature. The extracts were filtered using whatman No. 1 filter paper and separately concentrated on rotatory evaporator at $37^{\circ} \mathrm{C}$, stored in labeled, sterile, screwcapped bottles and allowed for complete dryness by putting them inside desiccators. Successive partitioned was done in the order of n-Hexane, dichloromethane and methanol for the stem bark extract while the root ethanol extract was chromatographed directly.

\section{Column Chromatography of dichloromethane extract of $U$. guineensis stem bark}

The dichloromethane extract $(6.9 \mathrm{~g})$ of $U$. guineensis (stem bark) was preadsorbed on silica gel $(6.9 \mathrm{~g})$ to form a homogenous mixture which was subjected to column chromatography (weight of silica gel $200 \mathrm{~g}$, length $=70 \mathrm{~cm}$, internal diameter (id) $=4 \mathrm{~cm}$ ) using gradient of hexane, dichloromethane (DCM), ethyl acetate $(\mathrm{EtOAc})$ and methanol $(\mathrm{MeOH})$ in order of hexane: $(100 \%, 200 \mathrm{~mL})$; hexane: DCM $(9: 1,200 \mathrm{~mL})$; (4:1, $100 \mathrm{~mL}) ;(7: 3,80 \mathrm{~mL}) ;(3: 2,620 \mathrm{~mL}) ;(1: 1,280$ $\mathrm{mL}) ;(2: 3,460 \mathrm{~mL}) ;(3: 7,260 \mathrm{~mL}) ;(1: 4,300 \mathrm{~mL}) ;(1: 9$, $220 \mathrm{~mL})$; DCM (100\%, $660 \mathrm{~mL})$; DCM: EtOAc: $(9: 1$, $100 \mathrm{~mL}) ;(4: 1,320 \mathrm{~mL}) ;(7: 3,380 \mathrm{~mL}) ;(3: 2,260 \mathrm{~mL})$; $(1: 1,180 \mathrm{~mL}) ;(2: 3,160 \mathrm{~mL}) ;(3: 7,160 \mathrm{~mL}) ;(1: 4,180$ $\mathrm{mL}) ;(1: 9,260 \mathrm{~mL})$; EtOAc $(100 \%, 360 \mathrm{~mL})$; EtOAc: $\mathrm{MeOH} ;(9: 1,620 \mathrm{~mL})$ and $(4: 1,200 \mathrm{~mL})$ separately. A total of 328 fractions (20 mL each) were collected and pooled to 16 sub-fractions $\left(D_{1-16}\right)$ based on TLC analysis. The sub-fraction $D_{13}$ eluted with DCM: EtOAc, 4:1 was developed in a TLC tank with solvent ratio of 9.5:0.5 (DCM: $\mathrm{MeOH})$. The isolate is UV inactive and gave a single spot when sprayed with cerium sulphate $\left(R_{f}=0.51\right)$. The whitish powder was re-crystallised in methanol to give a colourless needles powder coded DBG-D $D_{13}(25.0 \mathrm{mg})$.

\section{Column Chromatography of Methanol fraction of U. guineensis stem bark}

Methanol extract $(17.9 \mathrm{~g})$ of $U$. guineensis (stem bark) was mixed with equal weight of silica gel and chromatographed (silica gel weight $=350 \mathrm{~g}$, length $=$ $80 \mathrm{~cm}$, id $=6 \mathrm{~cm}$ ). Elution was carried out using gradient of hexane, ethyl acetate and methanol in order of hexane: $(100 \%, 500 \mathrm{~mL})$; hexane: ethyl acetate: $(1: 1,700 \mathrm{~mL}) ;(2: 3,600 \mathrm{~mL}) ;(3: 7,500 \mathrm{~mL})$; (1:4, $500 \mathrm{~mL}) ;(1: 9,500 \mathrm{~mL})$; ethyl acetate: $(100 \%, 500$ $\mathrm{mL})$; ethyl acetate: methanol: $(9: 1,300 \mathrm{~mL}) ;(4: 1,300$ $\mathrm{mL})$ and $(7: 3,700 \mathrm{~mL})$. A total of 51 fractions of 100 $\mathrm{mL}$ each were collected and pooled to 4 sub-fractions 
(P-S) based on their TLC profile. Fraction Q $(2.5 \mathrm{~g})$ eluted between $50-70 \%$ EtOAc in Hexane was further subjected to a silica gel column chromatography (weight of silica gel $=70 \mathrm{~g}$, length $=60 \mathrm{~cm}$, id $=2.5$ $\mathrm{cm})$ using isocratic elution of hexane: EtOAc (3:7). Fourteen fractions were collected at $30 \mathrm{~mL}$ each and pooled to 5 sub-fractions ( $\left.Q_{1-5}\right)$ based on their TLC profile. Fraction $Q_{3}$ was analyzed on TLC with Hexane: EtOAc system (3:7) to give a single spot on spraying with cerium sulphate $\left(R_{f}=0.53\right)$. It gave a dirty whitish powder which was re-crystallised in dichloromethane to give a clean white powder coded MBG- $Q_{3}(6.1 \mathrm{mg})$.

\section{Column Chromatography of ethanol extract of $U$. guineensis (root)}

The ethanol extract $(12.9 \mathrm{~g})$ of $U$. guineensis was homogenised with equal weight of silica gel and subjected to column chromatography using silica gel (weight of silica gel $=370 \mathrm{~g}$, length $=80 \mathrm{~cm}$, id $=6$ $\mathrm{cm})$. Elution was carried out using gradient of hexane, dichloromethane, ethyl acetate and methanol in order of hexane; $(100 \%, 2800 \mathrm{~mL})$, hexane: dichloromethane; (9:1, $1600 \mathrm{~mL}) ;(4: 1,400 \mathrm{~mL}) ;(7: 3$, $600 \mathrm{~mL}) ;(3: 2,600 \mathrm{~mL}) ;(1: 1,600 \mathrm{~mL}) ;(2: 3,400 \mathrm{~mL})$; $(3: 7,400 \mathrm{~mL}) ;(1: 4,400 \mathrm{~mL}), \quad(1: 9,400 \mathrm{~mL})$, dichloromethane; $(100 \%, 400 \mathrm{~mL})$, dichloromethane: ethyl acetate; (9:1, $900 \mathrm{~mL}) ;(4: 1,900 \mathrm{~mL}) ;(7: 3,500$ $\mathrm{mL}) ;(3: 2,400 \mathrm{~mL}) ;(1: 1,300 \mathrm{~mL}) ;(2: 3,600 \mathrm{~mL}) ;(3: 7$, $400 \mathrm{~mL}) ;(1: 4,600 \mathrm{~mL}),(1: 9,400 \mathrm{~mL})$, ethyl acetate; $(100 \%, 600 \mathrm{~mL})$, ethyl acetate: methanol; $(9: 1,1000$ $\mathrm{mL}) ;(4: 1,400 \mathrm{~mL}) ;(7: 3,2100 \mathrm{~mL})$; separately to give 177 fractions at $100 \mathrm{~mL}$ which were pooled to 9 subfractions $\left(E_{1-9}\right)$ using TLC analysis. The sub-fraction $E_{6}$ $(340.0 \mathrm{mg})$ eluted with $10 \%$ ethyl acetate: dichloromethane was further purified while sub-fraction $\mathrm{E}_{7}$ eluted between $20-50 \%$ ethyl acetate: dichloromethane was developed in TLC tank with solvent ratio 3:7 (EtOAc: Hexane) to give a brown single spot on spraying with cerium sulphate $\left(R_{f}=\right.$ 0.52 ). The sample was a dirty white crystalline powder which was re-crystallised in methanol to give clean white powder coded ERG-E7 (20.0 mg)

\section{RESULTS AND DISCUSSION}

Compound 1 was obtained as colourless needles powder with yield $(25.0 \mathrm{mg})$ and melting point $279-280$ ${ }^{\circ} \mathrm{C}$. The IR spectrum of DBG- $\mathrm{D}_{13}$ showed diagnostic absorption bands for $\mathrm{O}-\mathrm{H}, \mathrm{C}-\mathrm{H}_{\text {str. }}, \mathrm{C}=\mathrm{O}, \mathrm{C}=\mathrm{C}$ and $\mathrm{C}$ $H_{\text {bend }}$ at $3447,2942 / 2870,1688,1648$ and $1457 \mathrm{~cm}^{-1}$ respectively. The UV spectrum showed a single band at $207 \mathrm{~nm}$. The ${ }^{1} \mathrm{H}$ NMR showed pattern characteristic of lupane type skeleton. The methylene protons on C16 and $\mathrm{C}-22$ resonated as triplet of triplet at $\delta$ 2.23/1.44 (2H, tt, $J=3.0 / 12.5 \mathrm{~Hz}, \mathrm{H}-16)$ and 1.53/1.17 $(2 \mathrm{H}, \mathrm{tt}, J=3.0 / 13.0 \mathrm{~Hz}, \mathrm{H}-22)$ respectively. The spectrum also showed a one proton broad singlet at $\delta$ 3.30 and 10.5 which are characteristic of a hydroxyl and a carboxylic acid signals respectively. The methine protons on $\mathrm{C}-19$ and $\mathrm{C}-13$ also showed signals for two doublet of doublet of doublet (triplet of doublet) at $\delta 3.04(1 \mathrm{H}, \mathrm{ddd}, J=5.0 / 11.0 \mathrm{~Hz}, \mathrm{H}-19)$ and $2.33(1 \mathrm{H}, \mathrm{ddd}, J=2.5 / 11.5 \mathrm{~Hz}, \mathrm{H}-13)$. The triplet at $\delta$
$3.10(1 \mathrm{H}, \mathrm{t}, J=5.0 \mathrm{~Hz}, \mathrm{H}-3)$ was assigned to the proton at $\mathrm{C}-3$. There is exomethylene group signal at $\delta$ 4.71 and $4.58(1 \mathrm{H}$, each dd, $J=2.5 / 2.0 \mathrm{~Hz}, \mathrm{H}-29)$ which together with an allylic methyl at $\delta 1.68(3 \mathrm{H}, \mathrm{s}$, $\mathrm{H}-30$ ) indicated an isopropenyl moiety. The other five methyl groups resonated at $\delta 1.01,0.95,0.94,0.84$ and 0.74 . The ${ }^{13} \mathrm{C}$ NMR spectrum displayed thirty carbon resonances which were sorted using Distortionless Enhancement by Polarisation Transfer (DEPT) experiment as six methyl carbons $\{\delta c 28.5$ (C23), 16.1 (C-24), 16.5 (C-25), 16.6 (C-26), 15.0 (C-27) and $19.5(\mathrm{C}-30)\}$, eleven methylene carbons $\{\delta \mathrm{C} 109.9$ (C-29), 39.5 (C-1), 30.4 (C-21), 35.2 (C-7), 32.8 (C16), 31.3 (C-15), 37.5 (C-22), 28.3 (C-2), 26.4 (C-12), $21.7(\mathrm{C}-11)$ and $19.1(\mathrm{C}-6)\}$, six methine carbons $\{78.5$ (C-3), 56.3 (C-5), 51.4 (C-9), 49.9 (C-18), 47.9 (C-19) and $39.0(\mathrm{C}-13)\}$, six quaternary carbons $\{151.6(\mathrm{C}-$ 20), 56.8 (C-17), 43.0 (C-14), 41.5 (C-8), 39.6 (C-4) and $37.9(\mathrm{C}-10)\}$ and one carbonyl carbon $\{177.5$ (C28)\}. The assignment of chemical shifts of the protonated carbons was achieved by a Heteronuclear Multiple Quantum Correlation (HSQC) experiment. The ${ }^{1} \mathrm{H}-{ }^{-1} \mathrm{H}$ Correlation Spectroscopy experiment (COSY) showed cross peaks for coupled protons at position 2 and $3,7 \mathrm{a}$ and $7 \mathrm{~b}, 12$ and 13,13 and 18,19 and 21,22 and 21,23 and 24 for DBG-D 13 . The Nuclear Overhauser Effect Spectroscopy (NOESY) experiment showed non coupling of protons at position 23 and 24 with its neighbouring protons at 3 suggesting $\beta$ orientation of the hydroxyl group at C-3. The entire long ranged $\left\{{ }^{2} \mathrm{~J}(\mathrm{CH})\right.$ and $\left.{ }^{3} \mathrm{~J}(\mathrm{CH})\right\}$ connections between the protons and carbons were observed in the Heteronuclear Multiple Bond Correlation (HMBC) spectrum. The El-MS showed m/z 456.3 calculated for a molecular formula $\mathrm{C}_{30} \mathrm{H}_{48} \mathrm{O}_{3}$ with $\mathrm{HRMS}$ of 456.3598 . Comparison of DBG-D $D_{13}$ spectroscopic data with that of betulinic acid reported in literature [11] showed similarity. The structure of DBG-D $D_{13}$ was elucidated to be 3ß-hydroxy-20(29)-lupen-28-oic acid.

Compound 2 was obtained as a whitish powder with molecular ion peak at $\mathrm{m} / \mathrm{z} 456.0$ in El-MS (positive ion mode) which matched with high-resolution mass spectrometry (HRMS) $\mathrm{C}_{30} \mathrm{H}_{48} \mathrm{O}_{3}$ (456.3598). The IR spectrum of MBG-Q $Q_{3}$ showed a broad peak of hydroxyl group at $3454 \mathrm{~cm}^{-1}$, prominent carbonyl absorption at $1687 \mathrm{~cm}^{-1}$, double bonded peaks at $1641 \mathrm{~cm}^{-1}$ and other diagnostic bands like 2942/2871 ( $\left.\mathrm{C}-\mathrm{H}_{\text {str. }}\right), 3075$ $(=\mathrm{C}-\mathrm{H})$ and $1452\left(\mathrm{C}-\mathrm{H}_{\text {bend }}\right) \mathrm{cm}^{-1}$. The UV spectrum showed a single band at $206 \mathrm{~nm}$. The ${ }^{1} \mathrm{H}$ NMR spectrum of MBG-Q3 showed pattern characteristic of a lupane type carbon skeleton. The compound indicated six singlet methyl proton signals at $\delta 0.74(\mathrm{~s}$, $\mathrm{H}-25), 0.85$ (s, H-24), 0.94 (s, H-26), 0.96 (s, H-27), $0.99(\mathrm{~s}, \mathrm{H}-23)$ and $1.69(\mathrm{~s}, \mathrm{H}-30)$. It also contains two proton signals corresponding to olefinic methylene proton at $\delta 4.70(\mathrm{~s}, \mathrm{H}-29 \mathrm{a})$ and $4.58(\mathrm{~s}, \mathrm{H}-29 \mathrm{~b})$, which correlated with the ${ }^{13} \mathrm{CNMR}$ signal at $\delta 19.6$ (C-30). The doublet of doublet at $\delta 3.11(1 \mathrm{H}, \mathrm{dd}, J=4.5 / 11.0 \mathrm{~Hz})$ could be assigned to $\mathrm{H}-3$ with the vicinyl methylene protons suggested $\beta$ orientation of the hydroxyl group at C-3. The methylene proton at C-16 and C-22 showed triplet of triplet at $\delta 2.21 / 1.40(2 \mathrm{H}, \mathrm{tt}, J=$ 3.5/13.0 Hz, H-16) and 1.18/1.51 (2H, tt, $J=3.0 / 13.5$ 
$\mathrm{Hz}, \mathrm{H}-22)$. The spectrum also showed triplet of doublets (doublet of doublet of doublet) at $\delta 2.33(1 \mathrm{H}$, ddd, $J=2.5 / 11.5 \mathrm{~Hz}, \mathrm{H}-13)$ and $\delta 3.02(1 \mathrm{H}$, ddd, $J=$ $5.0 / 11.0 \mathrm{~Hz}, \mathrm{H}-19)$ for the methine proton at $\mathrm{C}-13$ and C-19 respectively. A total of thirty carbons resonances where observed in ${ }^{13} \mathrm{C}$ NMR spectrum which were sorted using DEPT experiment into six methyl carbons, eleven methylene carbons, six methine carbons, six quaternary carbons and one carbonyl carbon. Among the signals are olefinic methylene carbon signal at $\delta 110.1$ (C-29) and carboxylic group carbon signal at $\delta 180.5$ (C-28). Further information about the compound was obtained from the typical ElMS related to the fragmentation pattern of lupine type triterpenes through the presence of $\mathrm{m} / \mathrm{z} 438\left(\mathrm{M}-\mathrm{H}_{2} \mathrm{O}\right)$, $411(\mathrm{M}-\mathrm{COOH}), 248\left(\mathrm{C}_{16} \mathrm{H}_{24} \mathrm{O}_{2}\right), 220\left(\mathrm{C}_{15} \mathrm{H}_{24} \mathrm{O}\right), 203$ (248-COOH), $207\left(\mathrm{C}_{14} \mathrm{H}_{23} \mathrm{O}\right)$ and $189\left(207-\mathrm{H}_{2} \mathrm{O}\right)$ which are characteristics peaks for betullinic acid [13]. Seven degree of unsaturation corresponding to five rings, a double bond and one acidic carbonyl in the molecule. The mass fragmentation pattern also confirms the molecular ion. The assignment of chemical shifts of the protonated carbons was achieved by a Heteronuclear Multiple Quantum Correlation (HSQC) experiment. The ${ }^{1} \mathrm{H}-{ }^{1} \mathrm{H}$ Correlation Spectroscopy experiment (COSY) showed cross peaks for coupled protons at position 2 and 3,5 and 6,12 and 13, 15 and 16, 13 and 18, 18 and 19, 21 and 22, 23 and 24 for MBG-Q13. The Nuclear Overhauser Effect Spectroscopy (NOESY) experiment confirms a orientation of the hydroxyl group at C-3. This is due to the coupling of protons at position 23 and 24 with its neighbouring protons at position 3 based on orientations. The HMBC showed connectivity between the proton in position 18 and the $\mathrm{C}=\mathrm{O}(180.5)$ in position 28 confirming the presence of a carboxylic group not shown in the ${ }^{1} \mathrm{H}$ NMR spectrum. Comparison of MBG-Q 3 spectroscopic data with that of betulinic acid reported in literature [11] showed similarity. The structure of $M B G-Q_{3}$ was elucidated to be 3a-hydroxy-20(29)-lupen-28-oic acid. The compound 3 showed diagnostic IR absorption bands for $\mathrm{O}-\mathrm{H}, \mathrm{C}-\mathrm{H}_{\text {str., }} \mathrm{C}=\mathrm{O}$, and $\mathrm{C}-\mathrm{H}_{\text {bend }}$ at 3307 , 2941/2869, 1687 and $1456 \mathrm{~cm}^{-1}$ respectively. The UV spectrum showed a single band at $207 \mathrm{~nm}$ which indicated $n \rightarrow \Pi^{*}$ transition of carbonyl group of carboxylic acid. The ${ }^{1} \mathrm{H}$ NMR spectrum of $\mathrm{ERG}-\mathrm{E}_{7}$ showed pattern characteristic of a lupane-type carbon skeleton. It displayed signals attributed to exomethylene group at $\delta 4.71$ and $4.58(1 \mathrm{H}$, each dd, $J=2.0 / 2.4 \mathrm{~Hz}, \mathrm{H}-29)$ which together with an allylic methyl at $\delta 1.69$ which indicated an isopropenyl moiety. The double doublet at $\delta 3.11(1 \mathrm{H}$, dd, $J=$ $11.0 / 11.5 \mathrm{~Hz}$ ) was assigned to $\mathrm{H}-3$ with the vicinyl methylene protons suggested a $\beta$ orientation of the hydroxyl group at $\mathrm{C}-3$. The spectrum also showed a triplet of doublet at $\delta 2.33(1 \mathrm{H}$, ddd, $J=3.6 / 12.4 \mathrm{~Hz}, \mathrm{H}$ 13) and $\delta 3.05(1 \mathrm{H}$, ddd, $J=5.2 / 10.8 \mathrm{~Hz}, \mathrm{H}-19)$ for the methine proton at $\mathrm{C}-13$ and $\mathrm{C}-19$ while the triplet of triplet at $\delta 2.21 / 1.36(2 \mathrm{H}, \mathrm{tt}, J=3.6 / 12.4 \mathrm{~Hz}, \mathrm{H}-16)$ and $\delta 1.19 / 1.51(2 \mathrm{H}, \mathrm{tt}, J=2.8 / 13.2 \mathrm{~Hz}, \mathrm{H}-22)$ accounted for the methylene proton at $\mathrm{C}-16$ and $\mathrm{C}-22$. The other five methyl groups resonated at $\delta 1.01,0.95,0.94$, 0.84 and 0.74 . There also exist signals at $\delta 3.31(1 \mathrm{H}$, br. s) for alcoholic $\mathrm{OH}$ and $\delta 10.6(1 \mathrm{H}$, br. s) for carboxylic OH [19]. The El-MS showed $\mathrm{m} / \mathrm{z} 456.1$ which was confirmed with High Resolution Mass Spectroscopy (HRMS) for a molecular formula $\mathrm{C}_{30} \mathrm{H}_{48} \mathrm{O}_{3}$ (456.3598). The structure of $E R G-E_{7}$ was elucidated to be 3a-hydroxy-20(29)-lupen-28-oic acid. Comparison of MBG-Q3, DBG-D 13 and ERG-E 7 with betulinic acid showed similarity in spectroscopic data $[14,15]$ as shown in Table 1. They are all betullinic acid except that the hydroxyl group at $\mathrm{C}-3$ is a-oriented for $M B G-Q_{3}$ and $\beta$-oriented for DBG-D 13 and ERG-E7. This was also confirmed through NOESY experiment. The structures were elucidated to be $3 \alpha$-hydroxy20(29)-lupen-28-oic acid and 3ß-hydroxy-20(29)lupen-28-oic acid as shown in Fig. 1.

Table 1. ${ }^{13} \mathrm{C}$ NMR Data for DBG-D ${ }_{13}, M B G-Q_{3}$ and ERG-E 7 compared to Betulinic Acid

\begin{tabular}{|c|c|c|c|c|c|}
\hline $\begin{array}{l}\text { Assign } \\
\text { ment }\end{array}$ & $\begin{array}{l}\text { DBG- } \\
D_{13}\end{array}$ & $\begin{array}{l}\text { MBG- } \\
Q_{3}\end{array}$ & $\begin{array}{l}\text { ERG- } \\
E_{7}\end{array}$ & $\begin{array}{l}\text { Betulinic } \\
\text { acid }\end{array}$ & DEP1 \\
\hline 1. & 39.5 & 39.9 & 40.1 & $39.77 \mathrm{~s}$ & $\mathrm{CH}_{2}$ \\
\hline 2. & 28.3 & 28.1 & 28.1 & $28.79 t$ & $\mathrm{CH}_{2}$ \\
\hline 3. & 78.5 & 79.7 & 79.7 & $78.60 d$ & $\mathrm{CH}$ \\
\hline 4. & 39.6 & 40.1 & 38.3 & $39.99 \mathrm{~s}$ & C \\
\hline 5. & 56.3 & 56.9 & 56.9 & $56.41 d$ & $\mathrm{CH}$ \\
\hline 6. & 19.1 & 19.5 & 19.5 & $19.26 t$ & $\mathrm{CH}_{2}$ \\
\hline 7. & 35.2 & 35.6 & 35.6 & $35.32 \mathrm{t}$ & $\mathrm{CH}_{2}$ \\
\hline 8. & 41.5 & 41.9 & 41.9 & $41.60 \mathrm{~s}$ & C \\
\hline 9. & 51.4 & 52.0 & 52.0 & $51.44 d$ & $\mathrm{CH}$ \\
\hline 10. & 37.9 & 38.3 & 39.9 & $38.00 \mathrm{~s}$ & C \\
\hline 11. & 21.7 & 22.1 & 22.1 & $21.69 t$ & $\mathrm{CH}_{2}$ \\
\hline 12. & 26.4 & 26.9 & 26.9 & $26.60 t$ & $\mathrm{CH}_{2}$ \\
\hline 13. & 39.0 & 39.7 & 39.7 & $39.10 d$ & $\mathrm{CH}$ \\
\hline 14. & 43.0 & 43.6 & 43.6 & $43.33 \mathrm{~s}$ & C \\
\hline 15. & 31.3 & 31.7 & 31.7 & $31.70 \mathrm{t}$ & $\mathrm{CH}_{2}$ \\
\hline 16. & 32.8 & 33.4 & 33.4 & $33.36 t$ & $\mathrm{CH}_{2}$ \\
\hline 17. & 56.8 & 57.5 & 57.5 & $57.11 \mathrm{~s}$ & C \\
\hline 18. & 49.9 & 50.5 & 50.5 & $50.26 d$ & $\mathrm{CH}$ \\
\hline 19. & 47.9 & 49.6 & 49.6 & $48.25 d$ & $\mathrm{CH}$ \\
\hline 20. & 151.6 & 152.1 & 152.1 & $151.80 \mathrm{~s}$ & C \\
\hline 21. & 30.4 & 30.9 & 30.9 & $30.76 t$ & $\mathrm{CH}_{2}$ \\
\hline 22. & 37.5 & 38.2 & 38.2 & $38.06 t$ & $\mathrm{CH}_{2}$ \\
\hline 23. & 28.5 & 28.6 & 28.6 & $29.14 q$ & $\mathrm{CH}_{3}$ \\
\hline 24. & 16.1 & 16.1 & 16.1 & $16.80 q$ & $\mathrm{CH}_{3}$ \\
\hline
\end{tabular}




$\begin{array}{llllll}25 . & 16.5 & 16.6 & 16.7 & 16.90 \mathrm{q} & \mathrm{CH}_{3} \\ 26 . & 16.6 & 16.7 & 16.7 & 16.90 \mathrm{q} & \mathrm{CH}_{3} \\ 27 . & 15.0 & 15.1 & 15.1 & 15.38 \mathrm{q} & \mathrm{CH}_{3} \\ 28 . & 177.5 & 180.5 & 180.5 & 179.32 \mathrm{~s} & \mathrm{C}=\mathrm{O} \\ 29 . & 109.9 & 110.1 & 110.1 & 110.41 \mathrm{t} & \mathrm{CH}_{2} \\ 30 . & 19.5 & 19.6 & 19.6 & 19.95 \mathrm{q} & \mathrm{CH}_{3}\end{array}$

Ref. [14, 15]

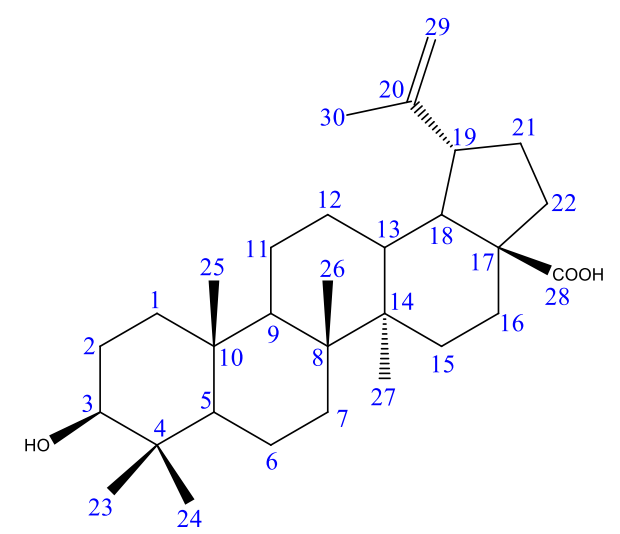

Compounds 1 and 3

(3-beta-hydroxy-20(29)-lupen-28-oic acid)

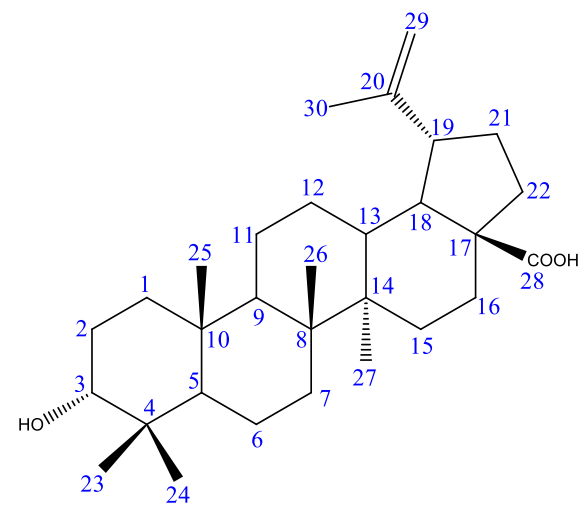

Compound 2

(3-alpha-hydroxy-20(29)-lupen-28-oic acid)

Fig. 1. Structures of Compounds 1, 2 and 3

\section{CONCLUSION}

In conclusion, the present work confirms the isolation of large amount of betulinic acid from dichloromethane, methanol, (stem bark) and ethanol extract (root) of Uapaca guineensis with $\alpha$ and $\beta$ orientation. Similarly, the values of ${ }^{1}$ HNMR, IR, UV, EI-MS, HREI-MS, ${ }^{13} \mathrm{CNMR}$ and 2D-NMR obtained were in agreement with the literature values [15].

\section{ACKNOWLEDGEMENTS}

Authors are grateful to the Chemistry Department (Organic Unit), University of Ibadan where part of the work was carried out and H.E.J Research Institute of Chemistry, ICCBS, University of Karachi, Pakistan through the support and funding of TWAS/ICCBS Postgraduate fellowship which was awarded in the year 2012.

\section{COMPETING INTERESTS}

Authors have declared that no competing interests exist.

\section{AUTHORS' CONTRIBUTIONS}

This work was carried out in collaboration between all Authors. 'Author IO' designed the study, performed the statistical analysis and wrote the protocol. 'Author AO' managed the analyses of the study, wrote the first and final draft of the manuscript. 'Author $\mathrm{PO}$ and $\mathrm{AO}^{\prime}$ ' managed the literature searches. 'Author IC and IO' monitored the analyses and provided major equipments used. All authors read and approved the final manuscript."

\section{CONSENT}

It is not applicable.

\section{ETHICAL APPROVAL}

It is not applicable.

\section{REFERENCES}

[1] Boulos L. Medicinal Plants of North Africa. Publ. Firewood, Egypt. 1980: 83.

[2] Tackholm V. Students Flora of Egypt 2nd ed. Publ. Cairo Univ., Berirut, 1974: 319-332.

[3] Mabberley DJ. The plant book. A portable dictionary of the vascular plants. 2nd ed. Cambridge University Press; 1997.

[4] Barthelemy N, Jean-Jules N, Yves N, Igor N, Bernd $S$. Uapaca genus (Euphorbiaceae), a good source of betulinic acid. Fitoterapia 2009: 80: 32-34.

[5] Ndebia EJ, Nkeh-Chungag BN, Temdie JR, Fodjo YM, Ndinteh DT, Mbafor JT. Antinociceptive effects of the methanol extract of Uapaca guineensis (euphorbiaceae) stilt root bark. Pharmacologyonline 2007: 3: 153-165.

[6] Muchuweti M, Ndhlala AR, Kasiamhuru A. Analysis of phenolic compounds including tannins, gallotannins and flavonols of Uapaca kirkiana fruit. Food Chem, 2006: 94: 415-419.

[7] Buske A, Schmidt J, Hoffmann P. Chemotaxonomy of the tribe Antidesmeae (Euphorbiaceae): 
antidesmone and related compounds. Phytochem. 2002: 60 (5): 489-96.

[8] Steele JCP, Warhurst DC, Kirby GC, Simmonds MSJ. In vitro and In vivo evaluation of betulinic acid as an antimalarial. Phytotherapy Research. 1999: 13 (2): 115-119.

[9] Berhaut J. Flore du Sénégal. Dicotyledones. Tome III. Cannaraceae à Euphorbiaceae, Dakar, 1975: 3604.

[10] Burkill HM. The useful plants of West Tropical Africa. 2nd Edition. Volume 2, Families E-I. Royal Botanic Gardens, Kew, Richmond, United Kingdom. 1994: 636.

[11] Ayatollahi AM, Ghanadian M, Afsharypour S, Abdella OM, Mirzai M, Askari G. Pentacyclic Triterpenes in Euphorbia microsciadia with Their T-cell Proliferation Activity. Iranian J. of Pharmaceutical Research. 2001: 10 (2): 287-294.

[12] Betti JL. An ethnobotanical study of medicinal plants among the Baka pygmies in the Dja biosphere reserve, Cameroon. African Study Monographs 2004: 25 (1): 1-27.

[13] Budzikiewiez H, Djerassi C, Williams DH. Structure Elucidation of Natural Products by Mass Spectrometry. Holden day INC, San Francisco. 1964: 120-150.

[14] Cichewicz RH, Kouzi SA. Chemistry, Biological Activity, and Chemotherapeutic Potential of Betulinic Acid for the Prevention andTreatment of Cancer and HIV Infection Medicinal Research Reviews. 2004: 24 (1): $90-114$.
[15] Geum-Soog K, Seung EL, Tae-Sook J, ChunGeun P, Jung SS, Jung BK, et al., Human AcylCoA:Cholesterol Acyltransferase (hACAT)-inhibiting Triterpenes from Lythrum salicaria $L$. J. Korean Soc. Appl. Biol. Chem. 2011: 54 (4): 628-632.

[16] Kirby GC, Khumalo-Ngwenya NB, Grawehr BA, Fison, TW, Warhurst DC, Phillipson JD. Antimalarial activity from "Mhekara" Uapaca nitida Mull. Arg., a Tanzania tree. J. Ethnopharmacol, 1993: 40 (1): 4751.

[17] Koné WM, Atindehou KK, Terreaux C, Hosttetmann K, Traoré D, Dosso M. Traditional medicine in north Cote-d'Ivoire: Screening of 50 plants for antibacterial activity. J. Ethnopharmacol, 2004: 93: 43-49.

[18] Schmidt ML, Kuzmanoff KL, Ling-Indeck L, Pezzuto JM. Betulinic acid induces apoptosis in human neuroblastoma cell lines. Eur J Cancer. 1997; 33 (12): 2007-10.

[19] Muhit MA, Tareq SM, Apu AS, Basak D, Islam MS. Isolation and Identification of Compounds from the Leaf Extract of Dillenia indica Linn. Bangladesh Pharmaceutical Journal. 2010: 13 (1).

[20] Yinusa, I., George, N. I. and Amupitan, J. O. (2012). Isolation and bioactivity of pentacyclic triterpenoid (Betunilic acid) from the bark of Sarcocephalus latifolius (Smith Bruce). Journal of Natural Sciences Research, 2 (4). 